\title{
Estimation of Age of Infectious Bursal Disease Vaccination in Broiler Chickens in Haryana, India
}

\author{
Pooja Kundu ${ }^{1}$, G. Narang ${ }^{2}$, Naresh Kakkar ${ }^{3}$, Sushma Kajal ${ }^{2}$, \\ Rajesh Chhabra ${ }^{4}$ and N.K. Mahajan ${ }^{1}$
}

${ }^{1}$ Department of Veterinary Public Health and Epidemiology, ${ }^{2}$ Department of Veterinary Pathology, ${ }^{3}$ Department of Veterinary Microbiology, College of Veterinary Sciences, Lala Lajpat Rai University of Veterinary and Animal Sciences, Hisar- 125004, Haryana, India

${ }^{4}$ College Central Laboratory, College of Veterinary Sciences, Lala Lajpat Rai University of

Veterinary and Animal Sciences, Hisar- 125004, Haryana, India

*Corresponding author

A B S T R A C T

Infectious bursal disease (IBD) or Gumboro causes heavy economic losses in poultry industry. Farmers are facing the problems of Gumboro even in the vaccinated flocks. The

\begin{tabular}{|c|}
\hline Keywords \\
\hline $\begin{array}{l}\text { Infectious bursal } \\
\text { disease, Maternal } \\
\text { antibody, Titre, } \\
\text { Vaccination. }\end{array}$ \\
\hline Article Info \\
\hline $\begin{array}{l}\text { Accepted: } \\
26 \text { October } 2017 \\
\text { Available Online: } \\
10 \text { December } 2017\end{array}$ \\
\hline
\end{tabular}
control of IBD depends on appropriate immunization schedule and maintenance of good hygienic conditions on the farm. For estimating optimum day of vaccination in broiler chickens serum samples were collected from 18 hatcheries situated in different parts belonging to Jind, Panipat and Hisar district of Haryana. Maternal antibody (MAb) titre of all the serum samples collected from different hatcheries along with day of vaccination was calculated as per Deventer formula. Statistics was applied on this raw data and the uniformity of day-old broiler chicks was expressed as percentage of coefficient of variation (CV \%) which was in the range of $28.2 \%$ to $75.3 \%$. The vast range of MAb titre (2 to 13128) in different serum samples gave wide range of day of vaccination as calculated for individual samples of all the hatcheries and it came to be in the range of 7 to 19 days of age of vaccination. According to Deventer formula a flock showing variation of $>4$ days in the age of vaccination range needs to be vaccinated twice. Due to wide range of MAb titre, twice vaccination is advisable and the age of first vaccination came to be $9^{\text {th }}$ day and age for booster vaccination came to be $16^{\text {th }}$ day. However, further studies are required to strengthen the observations.

\section{Introduction}

Infectious bursal disease (IBD) or Gumboro disease is a highly contagious viral infection of poultry which causes heavy mortality and immunosuppression (Van den Berg et al., 1991). Infectious bursal disease virus (IBDV) belongs to genus Avibirnavirus under the Birnaviridae family and it is a ds-RNA, nonenveloped bi-segmented virion (Dobos et al.,
1979). The disease is clinically characterized by dullness, depression, loss of appetite, white watery diarrhoea, soiled vent, ruffled feathers, severe prostration followed by death. The virus infects dividing $\operatorname{IgM}+\mathrm{B}$ lymphocytes and the main site of viral replication is the bursa of Fabricius, where B cells are produced (Nakai and Hirai, 1981; Palmquist 
et al., 2006). Infectious bursal disease virus (IBDV) can also infect macrophages (Palmquist et al., 2006, Kim et al., 1998, Khatri et al., 2005). Infection spread orally via contaminated feed and water (Sharma et al., 2000).

Since the first report of IBD outbreak from Uttar Pradesh in India by Mohanty et al., (1971), the major work on the disease has been combined to diagnosis and characterization of virus. The disease causes heavy economic losses in poultry industries due to immunosuppression in subclinical cases (Jackwood and Sommer, 2010) and in acute cases; it is associated with mortality, haemorrhages and also bursal damage (Jackwood et al., 2009). Some strains of IBDV can cause mortality as high as $100 \%$ in a susceptible flock (Cao et al., 1998). Immuno-suppression makes birds susceptible to secondary diseases and lead to vaccination failures (Allan et al., 1972).

The emergence of variant or newer strains of the virus in the recent times has also been reported to cause vaccination failures (Moemen et al., 2014). Moreover, various attenuation levels of commercially available live vaccines for IBD lead to varying levels of immunosuppression increasing the birds' vulnerability to various infections.

Control of IBD poses one of the most challenging tasks in the poultry health management. The control of IBD depends on appropriate immunization schedule and maintenance of good hygienic conditions on the farm (Farooq et al., 2003). Vaccinating breeding hens with live attenuated or inactivated virus vaccine most effectively controlled the disease.

Induced antibodies are transferred to the young chicks via the egg yolk and protect the newly hatched chicks for the critical first few days of their life (Wyeth and Cullen, 1976). A high level of maternal antibodies will protect most young chickens against challenge by vvIBD virus for up to 3 weeks after hatching (Van den Berg, 2000). The half-life of maternal antibodies varies between breeds and it is approximately three days for broilers and five days for laying hens (Brandt et al., 2001). Thus, if the antibody titre of a chick at hatch is known, the time of maximum flock susceptibility to the wild or vaccinal virus can be determined. This information is very important when establishing the timing of vaccination programs (Van den berg, 2000).

Other experimental studies have shown that IBD vaccine virus may even be completely neutralized by maternally derived antibodies (MDAs) (Tsukamoto et al., 1995; Alam et al., 2002; Hair-Bejo et al., 2004; Moraes et al., 2005). Ahmed et al., (2003) reported that immune response against different IBD vaccines varied in accordance with the vaccine schedule and levels of maternal antibody against IBDV in the chicks. Chickens from more than one parent flock may be mixed in the same broiler house, adding to the variation in the level of maternally derived antibodies (MDA).

In order to have chickens protected from IBDV field challenge, it is crucial to determine the optimal timing for IBD vaccine delivery (Tsukamoto et al., 1995). The optimal timing is often predicted based on serological data following detection of IBDVMDA by an ELISA system during the first week post hatch (Kouwenhoven and Van den Bos, 1994).

The "Deventer formula" was developed to estimate the optimal vaccination time based on the half-life time of the MDA, the age of the chicken at sampling, genetic background, breakthrough titre of the vaccine, and the requested percentage of the flock having 
antibody levels below the breakthrough titre of the vaccine at the time of administration (De Wit, 2001). Generally vaccination is done at 12-15 day of age in broiler chickens. Inspite of extensive control measures the farmers are still facing the problems of Gumboro even in the vaccinated flocks (Hasan et al., 1998; Dias et al., 2009; Anonymous, 2015). Therefore, estimation of maternal antibody titre and age of vaccination in broiler chicken still remains a major area of concern and forms a prime area of research.

\section{Materials and Methods}

\section{Collection of samples}

Blood samples from minimum of ten chicks (day old) from 18 hatcheries in Haryana was collected to evaluate the maternal antibody titre. 2-3 ml blood was collected directly from heart of day old chicks. Blood samples were left at room temperature for 15-20 minutes and then samples were kept in refrigerator or cold area for 10 minutes. Serum was separated efficiently from the clotted blood samples. Serum vials were marked for identity and serum samples were preserved at $-20^{\circ} \mathrm{C}$ for maintaining its quality till further use.

\section{Test procedure}

An indirect enzyme linked immunosorbent assay was performed to detect the IBD antibody levels using IDEXX-IBD-ELISA kit (IDEXX, Westbrook, USA). The test was performed as per the manufacturer's instructions.

Serum samples were diluted five hundred fold (1:500) with serum diluent and $100 \mu \mathrm{l}$ of the diluted samples were added to the antigen coated wells. Positive and negative controls were included every time in the test. The plates were incubated at $18-26^{\circ} \mathrm{C}$ for $30 \mathrm{~min}$.
The contents of the wells were removed and the wells were washed three times with distilled water. Care was taken to avoid the drying of plate in between plate washings and prior to the addition of the next reagent. Plates were tapped onto absorbent material after the final wash to remove any residual wash fluid and after that $100 \mu \mathrm{l}$ of Goat Anti chicken Horse radish peroxidase conjugate was added to each well. The plates were incubated at 18 $26^{\circ} \mathrm{C}$ for 30 minutes. The plates were emptied and washed thrice with distilled water.

The residual droplets were removed by lightly tapping the plate over a filter paper pad. One hundred microliters of TMB substrate was added to each well and incubated in dark at $18-26^{\circ} \mathrm{C}$ for 15 minutes. Later, $100 \mu \mathrm{l}$ of stop solution was added to each well to stop the colour reaction. The absorbance values were measured at $650 \mathrm{~nm}$ wavelength in an ELISA reader.

Assay was considered to be valid only when the difference between positive control mean and negative control mean (PCX - NCX) was greater than 0.075 . The negative control mean absorbance should be less than or equal to 0.150. Serum samples with $\mathrm{S} / \mathrm{P}$ ratios of greater than or equal to 0.2 (titers greater than 396) were considered as positive. The presence or absence of antibody to IBD was determined by relating the A (650) value of the unknown to the positive control mean. Antibody titre was calculated using the equations provided in the ELISA kit.

\section{Calculation}

\section{Controls}

Negative control mean,

$\mathrm{NC} \overline{\mathrm{x}}=\frac{\mathrm{NC} 1 \mathrm{~A}(650)+\operatorname{NC2} A(650)}{2}$ 
NC1- Negative Control 1 value, NC2Negative Control 2 value

Positive control mean,

$P C \bar{x}=\frac{P C 1 A(650)+P C 2 A(650)}{2}$

PC1- Positive Control 1value, PC2- Positive Control 2 value

Validity criteria

$\mathrm{PC}^{\overline{\mathbf{x}}}-\mathrm{NC}^{\overline{\mathbf{x}}}>0.075$

$\mathrm{NC}^{\overline{\mathbf{x}} \leq 0.150}$

\section{Samples}

The relative level of antibody in the sample was determined by calculating sample to positive $(\mathrm{S} / \mathrm{P})$ ratio.

Sample to positive ratio, $\mathrm{S} / \mathrm{P}=$



$\mathrm{PCX}-\mathrm{NC} \overline{\mathrm{X}}$

Endpoint titres were calculated using equation

$\log _{10}$ Titer $=1.09\left(\log _{10} S / P\right)+3.36 *$

* relates $\mathrm{S} / \mathrm{P}$ at a 1: 500 dilution to an end point titre

\section{IDEXX ELISA standard for IBD antibody titre}

$\mathrm{S} / \mathrm{P}$ value Titre range Antibody status $<0.20<396 \quad$ negative

$\geq 0.20 \quad \geq 396 \quad$ positive

The optimal age of vaccination was determined by the Deventer formula (De Wit, 1998).
Vaccination age $=\{(\log 2$ titre bird\% $-\log 2$ breakthrough) $\left.\mathrm{x} \mathrm{t}_{-}\right\}+$age at sampling + correction0-4 in which Bird\% = ELISA titre of the bird representing a certain percentage of the flock.

Breakthrough $=$ breakthrough (ELISA) titre of the vaccine to be used (500 for intermediate plus vaccine)

$\mathrm{t}_{-}=$half-life time (ELISA) of the antibodies in the type of chickens being sampled (3.0 days)

Age at sampling $=$ age of the birds at sampling (1 day of age)

Correction 0-4 = extra days when the sampling was done at 0 to 4 days of age ( 3 for day old chicks).

\section{Statistical analysis}

Maternal antibody titres of different hatcheries were analyzed using the one-way analysis of variance (ANOVA) test, followed by Duncan post hoc test. Difference between groups were considered significant at $P<0.05$. The data was expressed as mean $\pm \mathrm{SE}$. The coefficient of variation (CV \%) of maternal antibody titre with in a hatchery was calculated. Alpha was set at 95\%. Statistical software SPSS ${ }^{\mathrm{TM}} 20.0$ (IBM, Corp. USA) was used.

\section{Results and Discussion}

A total of 291 serum samples of day old chicks were collected from 18 hatcheries situated in different parts belonging to Jind, Panipat and Hisar district of Haryana, India. All the samples were tested by using IDEXX ELISA kit (Fig. 1). Maternally derived antibody titres of all the serum samples collected from different hatcheries along with day of vaccination calculated as per Deventer 
formula is presented in Tables 1-6. The mean titres of hatcheries A, B, C, D, E, F, G, H, I, J, $\mathrm{K}, \mathrm{L}, \mathrm{M}, \mathrm{N}, \mathrm{O}, \mathrm{P}, \mathrm{Q}$ and $\mathrm{R}$ were 5089.26 , 5548.03, 4488.87, 263.40, 7006.25, 5332.42, 1231.25, 3083.54, 6716.11, 3281.88, 3378.90, 3307.08, 5364.99, 6899.31, 4585.66, 4031.42, 2368.09 and 5022.55 respectively. The highest mean titre was in hatchery $\mathrm{E}$ (7006.25) while lowest titre was in hatchery D (263.40). There was a vast variation in maternal antibody titres of day old chicks within and between hatcheries.

The uniformity of day-old broiler chicks can be estimated by serological profiling and expressed as a percentage of coefficient of variation $(\mathrm{CV} \%)$.

Good and poor uniformity are the coefficients of variation $<30 \%$ or $>30 \%$, respectively. Coefficient of variation was $53 \%$ in hatchery $\mathrm{A}, 58.7 \%$ in $\mathrm{B}, 35.8 \%$ in $\mathrm{C}, 46.1 \%$ in $\mathrm{D}$, $41.5 \%$ in $\mathrm{E}, 47.9 \%$ in $\mathrm{F}, 75.3 \%$ in $\mathrm{G}, 55.9 \%$ in $\mathrm{H}, 52.5 \%$ in $\mathrm{I}, 67.4 \%$ in $\mathrm{J}, 67.1 \%$ in $\mathrm{K}, 61.85$ in $\mathrm{L}, 45.1 \%$ in $\mathrm{M}, 34.4 \%$ in $\mathrm{N}, 28.2 \%$ in $\mathrm{O}$, $47.9 \%$ in $\mathrm{P}, 73.3 \%$ in $\mathrm{Q}$ and $50.8 \%$ in hatchery $\mathrm{R}$. Coefficient of variation was very high in all the hatcheries except $\mathrm{O}$ which indicate non-uniform MAb titres in them.

The vast range of $\mathrm{MAb}$ titre in different serum samples gave wide range of day of vaccination as calculated for individual samples of all the hatcheries and it ranged from 7-19 days (Table 1-6) as titre varied from 2-13128.

The mean of MAb titres and age of vaccination calculated as per Deventer formula is presented in Table 7.

Under conditions where in the range of day of vaccination is less than 4 days, one could estimate the day of single vaccination on the basis of MAb titres of $75 \%$ flock excluding upper $25 \%$ MAb titres. As per Deventer formula, the age of vaccination according to
Ab titre of $75 \%$ flock came to be 17 days of age for hatchery $\mathrm{E}$ and $\mathrm{N} ; 16$ days of age for hatchery $\mathrm{B}, \mathrm{F}$ and $\mathrm{M} ; 15$ days of age for hatchery A, C, O, P and R; 14 days of age for hatchery $\mathrm{H}, \mathrm{J}, \mathrm{K}$ and $\mathrm{L} ; 12$ days of age in hatchery Q; 8 days of age for hatchery $\mathrm{G}$ and 7 days of age for hatchery $\mathrm{D}$ (Table 7).

If we took average of lowest and highest age for day of vaccination calculated for individual samples of different hatcheries, the age of first vaccination came to be $9^{\text {th }}$ day and age for second vaccination came to be $16^{\text {th }}$ day as depicted in column 4 of the Table 7 . However if we calculate age of first and age for second vaccination as per Deventer formula on the basis of $40 \%$ and $90 \%$ flock, the age of first and second vaccination came to be $12.1 \approx 13$ and $16^{\text {th }}$ day respectively.

One way ANOVA revealed significant difference between MAb titres of serum samples from all the 18 hatcheries. Mcllroy et al., (1992) suggested that a high variation in MDA levels between birds make advisable to vaccinate a broiler flock twice to induce homogeneous protection in birds. Van den Berg and Meulemans, (1991); Tsukamoto et al., (1995) reported that to protect chickens against IBD, determination of optimal time for IBD vaccination is important.

Block et al., (2007) performed a field study on the significance of vaccination against IBD at the optimal time point in broiler flocks with maternally derived IBDV antibodies.

It was estimated that flocks vaccinated between 1 day before, at, or up to 3 days after the estimated optimal time point developed detectable humoral immunity up to 14 days post vaccination.

If birds had been vaccinated more than 1 day before the calculated optimal day of vaccination, the humoral immune response was delayed or non-detectable until slaughter. 
Table.1 Maternal antibody titre and age of vaccination in serum samples of hatcheries A, B, C

\begin{tabular}{|c|c|c|c|c|c|c|}
\hline & \multicolumn{2}{|c|}{ Hatchery A } & \multicolumn{2}{|c|}{ Hatchery B } & \multicolumn{2}{|c|}{ Hatchery C } \\
\hline Day of & \multicolumn{2}{|r|}{1} & \multicolumn{2}{|r|}{1} & \multicolumn{2}{|c|}{1} \\
\hline Sr.No. & $\begin{array}{c}\text { ELISA } \\
\text { titre }\end{array}$ & $\begin{array}{c}\text { Day of } \\
\text { vaccination }\end{array}$ & $\begin{array}{c}\text { ELISA } \\
\text { titre }\end{array}$ & $\begin{array}{c}\text { Day of } \\
\text { vaccination }\end{array}$ & ELISA titre & $\begin{array}{c}\text { Day of } \\
\text { vaccination }\end{array}$ \\
\hline 1 & 1668.12 & 10 & 678.29 & 7 & 1661.03 & 10 \\
\hline 2 & 2910.15 & 12 & 712.40 & 7 & 2130.53 & 11 \\
\hline 3 & 2963.95 & 12 & 1094.44 & 8 & 2345.16 & 11 \\
\hline 4 & 3143.84 & 12 & 2342.99 & 11 & 3024.10 & 12 \\
\hline 5 & 3151.57 & 12 & 2670.61 & 12 & 3331.17 & 13 \\
\hline 6 & 3456.78 & 13 & 2747.94 & 12 & 3391.80 & 13 \\
\hline 7 & 3575.08 & 13 & 3163.94 & 12 & 3551.12 & 13 \\
\hline 8 & 3827.03 & 13 & 3458.07 & 13 & 3733.22 & 13 \\
\hline 9 & 3921.38 & 13 & 3841.35 & 13 & 3913.59 & 13 \\
\hline 10 & 4086.94 & 13 & 5621.25 & 15 & 4150.83 & 14 \\
\hline 11 & 4088.26 & 13 & 5972.57 & 15 & 4278.85 & 14 \\
\hline 12 & 4169.94 & 14 & 6530.12 & 16 & 4645.20 & 14 \\
\hline 13 & 4313.85 & 14 & 6890.75 & 16 & 4739.69 & 14 \\
\hline 14 & 4625.45 & 14 & 7088.87 & 16 & 4956.88 & 14 \\
\hline 15 & 4754.58 & 14 & 7424.24 & 16 & 5527.45 & 15 \\
\hline 16 & 5053.88 & 14 & 7895.58 & 16 & 5939.28 & 15 \\
\hline 17 & 5454.33 & 15 & 8075.02 & 16 & 5973.62 & 15 \\
\hline 18 & 5528.51 & 15 & 8999.57 & 17 & 6172.31 & 15 \\
\hline 19 & 5598.72 & 15 & 9612.37 & 17 & 6393.17 & 15 \\
\hline 20 & 5769.14 & 15 & 10075.18 & 17 & 7183.29 & 16 \\
\hline 21 & 7159.15 & 16 & 11613.02 & 18 & 7223.90 & 16 \\
\hline 22 & 7554.31 & 16 & - & - & - & - \\
\hline 23 & 12238.50 & 18 & - & - & - & - \\
\hline 24 & 13128.76 & 19 & - & - & - & - \\
\hline mean $\pm \mathrm{SE}$ & $\begin{array}{l}5089.26 \pm \\
550.62 \\
\end{array}$ & \begin{tabular}{|l|}
$13.54 \pm$ \\
0.58 \\
\end{tabular} & $\begin{array}{l}5548.03 \pm \\
711.71 \\
\end{array}$ & $\begin{array}{l}13.81 \pm \\
0.73\end{array}$ & $\begin{array}{l}4488.87 \pm \\
350.77 \\
\end{array}$ & $\begin{array}{l}13.62 \pm \\
0.36\end{array}$ \\
\hline \multicolumn{7}{|c|}{$\begin{array}{l}\text { As per Deventer formula - Age of vaccination according to antibody titre of } \\
\text { (excluding birds of higher titre) }\end{array}$} \\
\hline $\begin{array}{l}75 \% \\
\text { flock }\end{array}$ & 5528.51 & 15 & 7895.58 & 16 & 5939.28 & 15 \\
\hline $\begin{array}{l}40 \% \\
\text { flock }\end{array}$ & 4086.94 & 13 & 3841.35 & 13 & 3913.59 & 13 \\
\hline $\begin{array}{r}90 \% \\
\text { flock }\end{array}$ & 7554.31 & 16 & 9612.37 & 17 & 6393.17 & 15 \\
\hline
\end{tabular}


Table.2 Maternal antibody titre and age of vaccination in serum samples of hatcheries D, E, F

\begin{tabular}{|c|c|c|c|c|c|c|c|}
\hline \multirow{2}{*}{\multicolumn{2}{|c|}{$\begin{array}{c}\text { Day of } \\
\text { sampling }\end{array}$}} & \multicolumn{2}{|c|}{ Hatchery D } & \multicolumn{2}{|c|}{ Hatchery E } & \multicolumn{2}{|c|}{ Hatchery F } \\
\hline & & \multicolumn{2}{|r|}{$\mathbf{1}$} & \multicolumn{2}{|c|}{1} & \multicolumn{2}{|r|}{1} \\
\hline \multicolumn{2}{|c|}{ Sr.No. } & $\begin{array}{c}\text { ELISA } \\
\text { titre }\end{array}$ & $\begin{array}{c}\text { Day of } \\
\text { vaccination }\end{array}$ & $\begin{array}{c}\text { ELISA } \\
\text { titre }\end{array}$ & $\begin{array}{c}\text { Day of } \\
\text { vaccination }\end{array}$ & $\begin{array}{c}\text { ELISA } \\
\text { titre }\end{array}$ & $\begin{array}{c}\text { Day of } \\
\text { vaccination }\end{array}$ \\
\hline \multicolumn{2}{|l|}{1} & 67.53 & 7.0 & 1504.33 & 9 & 1715.85 & 10 \\
\hline \multicolumn{2}{|l|}{2} & 109.05 & 7.0 & 1955.26 & 10 & 2120.13 & 11 \\
\hline \multicolumn{2}{|l|}{3} & 125.08 & 7.0 & 2773.33 & 11 & 2561.29 & 11 \\
\hline \multicolumn{2}{|l|}{4} & 130.70 & 7.0 & 4136.97 & 13 & 2883.29 & 12 \\
\hline \multicolumn{2}{|l|}{5} & 179.19 & 7.0 & 5871.90 & 15 & 3203.13 & 12 \\
\hline \multicolumn{2}{|l|}{6} & 214.85 & 7.0 & 5989.51 & 15 & 3589.40 & 13 \\
\hline \multicolumn{2}{|l|}{7} & 229.55 & 7.0 & 7431.55 & 16 & 4414.43 & 14 \\
\hline \multicolumn{2}{|l|}{8} & 244.33 & 7.0 & 7754.25 & 16 & 4685.32 & 14 \\
\hline \multicolumn{2}{|l|}{9} & 244.33 & 7.0 & 7771.97 & 16 & 5675.77 & 15 \\
\hline \multicolumn{2}{|l|}{10} & 285.34 & 7.0 & 7993.06 & 16 & 5732.59 & 15 \\
\hline \multicolumn{2}{|l|}{11} & 290.60 & 7.0 & 8055.53 & 16 & 5847.74 & 15 \\
\hline \multicolumn{2}{|l|}{12} & 329.12 & 7.0 & 8274.06 & 17 & 6362.02 & 15 \\
\hline \multicolumn{2}{|l|}{13} & 347.39 & 7.0 & 8339.48 & 17 & 6736.98 & 16 \\
\hline \multicolumn{2}{|l|}{14} & 364.20 & 7.0 & 9687.50 & 17 & 6824.82 & 16 \\
\hline \multicolumn{2}{|l|}{15} & 371.86 & 7.0 & 10280.23 & 17 & 8448.88 & 17 \\
\hline \multicolumn{2}{|l|}{16} & 426.63 & 7.0 & 10389.23 & 17 & 9248.52 & 17 \\
\hline \multicolumn{2}{|l|}{17} & 518.14 & 7.0 & 10898.09 & 17 & 10600.9 & 17 \\
\hline \multicolumn{2}{|c|}{ mean $\pm \mathrm{SE}$} & $\begin{array}{c}263.40 \pm \\
29.42\end{array}$ & $\begin{array}{c}7.0 \pm \\
0.0\end{array}$ & $\begin{array}{c}7006.25 \pm \\
705.91\end{array}$ & $\begin{array}{c}14.99 \pm \\
0.64\end{array}$ & $\begin{array}{c}5332.42 \pm \\
619.89\end{array}$ & $\begin{array}{c}14.12 \pm \\
0.55\end{array}$ \\
\hline \multicolumn{8}{|c|}{$\begin{array}{c}\text { As per Deventer formula - Age of vaccination according to antibody titre of } \\
\text { (excluding birds of higher titre) }\end{array}$} \\
\hline $\begin{array}{r}75 \% \\
\text { flock }\end{array}$ & & 347.39 & 7.0 & 8339.48 & 17 & 6736.98 & 16 \\
\hline $\begin{array}{l}40 \% \\
\text { flock }\end{array}$ & & 229.55 & 7.0 & 7431.55 & 16 & 4414.42 & 14 \\
\hline $\begin{array}{l}90 \% \\
\text { flock }\end{array}$ & & 371.86 & 7.0 & 10389.23 & 17 & 9248.52 & 17 \\
\hline
\end{tabular}


Table.3 Maternal antibody titre and age of vaccination in serum samples of hatcheries $\mathrm{G}, \mathrm{H}, \mathrm{I}$

\begin{tabular}{|c|c|c|c|c|c|c|}
\hline \multirow{2}{*}{$\begin{array}{c}\text { Day of } \\
\text { sampling } \\
\end{array}$} & \multicolumn{2}{|c|}{ Hatchery G } & \multicolumn{2}{|c|}{ Hatchery $\mathbf{H}$} & \multicolumn{2}{|c|}{ Hatchery I } \\
\hline & \multicolumn{2}{|r|}{$\mathbf{1}$} & \multicolumn{2}{|c|}{1} & \multicolumn{2}{|c|}{1} \\
\hline & $\begin{array}{l}\text { ELISA } \\
\text { titre }\end{array}$ & $\begin{array}{c}\text { Day of } \\
\text { vaccination }\end{array}$ & $\begin{array}{l}\text { ELISA } \\
\text { titre }\end{array}$ & $\begin{array}{c}\text { Day of } \\
\text { vaccination }\end{array}$ & ELISA titre & $\begin{array}{c}\text { Day of } \\
\text { vaccination }\end{array}$ \\
\hline 1 & 271.86 & 7 & 844.39 & 7 & 331.02 & 7 \\
\hline 2 & 317.75 & 7 & 1447.19 & 9 & 612.21 & 7 \\
\hline 3 & 399.55 & 7 & 1451.48 & 9 & 3564.94 & 13 \\
\hline 4 & 402.64 & 7 & 1598.83 & 9 & 4101.43 & 14 \\
\hline 5 & 514.99 & 7 & 1784.82 & 10 & 5461.84 & 15 \\
\hline 6 & 805.07 & 7 & 2212.11 & 11 & 5529.85 & 15 \\
\hline 7 & 829.62 & 7 & 2424.41 & 11 & 6154.67 & 15 \\
\hline 8 & 981.49 & 7 & 2775.59 & 12 & 6335.71 & 15 \\
\hline 9 & 1138.68 & 8 & 2984.47 & 12 & 7248.09 & 16 \\
\hline 10 & 1294.30 & 8 & 3173.50 & 12 & 9205.67 & 17 \\
\hline 11 & 1469.51 & 9 & 4262.05 & 14 & 9840.19 & 17 \\
\hline 12 & 1509.07 & 9 & 4415.17 & 14 & 10233.84 & 17 \\
\hline 13 & 2659.90 & 11 & 4735.98 & 14 & 10525.60 & 18 \\
\hline 14 & 2909.86 & 12 & 4976.82 & 14 & 10786.64 & 18 \\
\hline 15 & 2964.44 & 12 & 7166.29 & 16 & 10809.93 & 18 \\
\hline mean $\pm \mathrm{SE}$ & $\begin{array}{l}1231.25 \pm \\
239.65\end{array}$ & $\begin{array}{c}9 \pm \\
0.46\end{array}$ & $\begin{array}{l}3083.54 \pm \\
445.6\end{array}$ & $\begin{array}{c}11.43 \pm \\
0.65\end{array}$ & $\begin{array}{l}6716.11 \pm \\
912.06\end{array}$ & $\begin{array}{c}14.74 \pm \\
0.9\end{array}$ \\
\hline \multicolumn{7}{|c|}{$\begin{array}{l}\text { As per Deventer formula - Age of vaccination according to antibody titre of } \\
\text { (excluding birds of higher titre) }\end{array}$} \\
\hline $\begin{array}{r}75 \% \\
\text { flock }\end{array}$ & 1294.30 & 8 & 4415.17 & 14 & 10233.84 & 17 \\
\hline $\begin{array}{l}40 \% \\
\text { flock }\end{array}$ & 805.07 & 7 & 2212.11 & 11 & 5529.85 & 15 \\
\hline $\begin{array}{l}90 \% \\
\text { flock }\end{array}$ & 2909.86 & 12 & 4976.82 & 14 & 10786.64 & 18 \\
\hline
\end{tabular}


Table.4 Maternal antibody titre and age of vaccination in serum samples of hatcheries J, K, L

\begin{tabular}{|c|c|c|c|c|c|c|}
\hline & \multicolumn{2}{|c|}{ Hatchery J } & \multicolumn{2}{|c|}{ Hatchery K } & \multicolumn{2}{|c|}{ Hatchery L } \\
\hline Day of & \multicolumn{2}{|c|}{1} & \multicolumn{2}{|c|}{1} & \multicolumn{2}{|c|}{1} \\
\hline Sr.No. & $\begin{array}{c}\text { ELISA } \\
\text { titre }\end{array}$ & $\begin{array}{c}\text { Day of } \\
\text { vaccination }\end{array}$ & $\begin{array}{c}\text { ELISA } \\
\text { titre }\end{array}$ & $\begin{array}{c}\text { Day of } \\
\text { vaccination }\end{array}$ & $\begin{array}{c}\text { ELISA } \\
\text { titre }\end{array}$ & $\begin{array}{c}\text { Day of } \\
\text { vaccination }\end{array}$ \\
\hline 1 & 814.07 & 7 & 2 & 7 & 822.66 & 7 \\
\hline 2 & 1351.36 & 9 & 1156.78 & 8 & 848.90 & 9 \\
\hline 3 & 1630.86 & 9 & 1182.07 & 8 & 1420.18 & 9 \\
\hline 4 & 1707.26 & 10 & 1443.33 & 9 & 2087.56 & 11 \\
\hline 5 & 1794.42 & 10 & 2023.97 & 10 & 2191.24 & 11 \\
\hline 6 & 2005.89 & 10 & 2341.71 & 11 & 2396.22 & 11 \\
\hline 7 & 2316.28 & 11 & 2721.77 & 12 & 3693.61 & 13 \\
\hline 8 & 2408.30 & 11 & 4399.65 & 14 & 4105.17 & 14 \\
\hline 9 & 4471.65 & 14 & 4964.94 & 14 & 4271.90 & 14 \\
\hline 10 & 4707.59 & 14 & 5065.72 & 14 & 4459.88 & 14 \\
\hline 11 & 5451.79 & 15 & 5111.41 & 14 & 6111.18 & 15 \\
\hline 12 & 5885.88 & 15 & 5940.33 & 15 & 7276.52 & 16 \\
\hline 13 & 8114.17 & 16 & 7573.09 & 16 & & \\
\hline mean $\pm \mathrm{SE}$ & $\begin{array}{c}3281.88 \pm \\
614.19\end{array}$ & $\begin{array}{c}11.5 \pm \\
0.78\end{array}$ & $\begin{array}{c}3378.90 \pm \\
629.51\end{array}$ & $\begin{array}{c}11.55 \pm \\
0.86\end{array}$ & $\begin{array}{c}3307.08 \pm \\
590.34\end{array}$ & $\begin{array}{c}11.89 \pm \\
0.79\end{array}$ \\
\hline \multicolumn{7}{|c|}{$\begin{array}{l}\text { As per Deventer formula - Age of vaccination according to antibody titre of } \\
\text { (excluding birds of higher titre) }\end{array}$} \\
\hline $75 \%$ flock & 4707.59 & 14 & 5065.72 & 14 & 4271.90 & 14 \\
\hline $40 \%$ flock & 1794.42 & 10 & 2023.97 & 10 & 2191.24 & 11 \\
\hline $90 \%$ flock & 5885.88 & 15 & 5940.33 & 15 & 6111.18 & 15 \\
\hline
\end{tabular}


Table.5 Maternal antibody titre and age of vaccination in serum samples of hatcheries $\mathrm{M}, \mathrm{N}, \mathrm{O}$

\begin{tabular}{|c|c|c|c|c|c|c|}
\hline & \multicolumn{2}{|c|}{ Hatchery M } & \multicolumn{2}{|c|}{ Hatchery N } & \multicolumn{2}{|c|}{ Hatchery O } \\
\hline Day of & \multicolumn{2}{|c|}{1} & \multicolumn{2}{|c|}{1} & \multicolumn{2}{|c|}{1} \\
\hline Sr.No. & $\begin{array}{c}\text { ELISA } \\
\text { titre }\end{array}$ & $\begin{array}{c}\text { Day of } \\
\text { vaccination }\end{array}$ & ELISA titre & $\begin{array}{c}\text { Day of } \\
\text { vaccination }\end{array}$ & $\begin{array}{c}\text { ELISA } \\
\text { titre }\end{array}$ & $\begin{array}{c}\text { Day of } \\
\text { vaccination }\end{array}$ \\
\hline 1 & 2553.68 & 11 & 3040.98 & 12 & 1803.59 & 10 \\
\hline 2 & 3733.22 & 13 & 4116.86 & 14 & 3423.75 & 13 \\
\hline 3 & 3834.93 & 13 & 4293.01 & 14 & 3704.73 & 13 \\
\hline 4 & 3948.03 & 13 & 4959.72 & 14 & 3704.73 & 13 \\
\hline 5 & 4646.27 & 14 & 5386.72 & 15 & 3751.12 & 13 \\
\hline 6 & 4813.34 & 14 & 6372.06 & 15 & 4046.29 & 13 \\
\hline 7 & 5528.63 & 15 & 7390.81 & 16 & 4394.95 & 14 \\
\hline 8 & 6678 & 16 & 7407.50 & 16 & 4402.47 & 14 \\
\hline 9 & 6787.74 & 16 & 7744.89 & 16 & 4517.34 & 14 \\
\hline 10 & 11126.05 & 18 & 8144.35 & 16 & 4939.30 & 14 \\
\hline 11 & - & - & 8251.28 & 17 & 5186.68 & 15 \\
\hline 12 & - & - & 8696.55 & 17 & 5740.07 & 15 \\
\hline 13 & - & - & 8758.75 & 17 & 6163.38 & 15 \\
\hline 14 & - & - & 12026.88 & 18 & 6351.22 & 15 \\
\hline 15 & - & - & - & - & 6655.25 & 16 \\
\hline mean $\pm \mathrm{SE}$ & $\begin{array}{l}5364.99 \pm \\
765.22\end{array}$ & $\begin{array}{c}13.3 \pm \\
0.63\end{array}$ & $\begin{array}{l}6899.31 \pm \\
634.72\end{array}$ & $\begin{array}{c}15.41 \pm \\
0.43\end{array}$ & $\begin{array}{c}4585.66 \pm \\
333.90\end{array}$ & $\begin{array}{c}13.64 \pm \\
0.39\end{array}$ \\
\hline \multicolumn{7}{|c|}{$\begin{array}{l}\text { As per Deventer formula - Age of vaccination according to antibody titre of } \\
\text { (excluding birds of higher titre) }\end{array}$} \\
\hline $75 \%$ flock & 6678 & 16 & 8251.28 & 17 & 5740.07 & 15 \\
\hline $40 \%$ flock & 3948.03 & 13 & 6372.06 & 15 & 4046.29 & 13 \\
\hline $90 \%$ flock & 6787.74 & 16 & 8758.75 & 17 & 6351.22 & 15 \\
\hline
\end{tabular}


Table.6 Maternal antibody titre and age of vaccination in serum samples of hatcheries $\mathrm{P}, \mathrm{Q}, \mathrm{R}$

\begin{tabular}{|c|c|c|c|c|c|c|}
\hline & \multicolumn{2}{|c|}{ Hatchery P } & \multicolumn{2}{|c|}{ Hatchery Q } & \multicolumn{2}{|c|}{ Hatchery $\mathbf{R}$} \\
\hline Day of & \multicolumn{2}{|c|}{1} & \multicolumn{2}{|c|}{1} & \multicolumn{2}{|c|}{1} \\
\hline Sr.No. & $\begin{array}{c}\text { ELISA } \\
\text { titre }\end{array}$ & $\begin{array}{c}\text { Day of } \\
\text { vaccination }\end{array}$ & $\begin{array}{c}\text { ELISA } \\
\text { titre }\end{array}$ & $\begin{array}{c}\text { Day of } \\
\text { vaccination }\end{array}$ & $\begin{array}{c}\text { ELISA } \\
\text { titre }\end{array}$ & $\begin{array}{c}\text { Day of } \\
\text { vaccination }\end{array}$ \\
\hline 1 & 1410.76 & 9 & 24.97 & 7 & 1156.36 & 8 \\
\hline 2 & 1421.04 & 9 & 33.72 & 7 & 2307.36 & 11 \\
\hline 3 & 1672.07 & 10 & 1049.66 & 8 & 2402.04 & 11 \\
\hline 4 & 1814.08 & 10 & 1479.57 & 9 & 2656.30 & 12 \\
\hline 5 & 3057.86 & 12 & 1534.12 & 9 & 3397.51 & 13 \\
\hline 6 & 3409.94 & 13 & 1535.34 & 9 & 3700.56 & 13 \\
\hline 7 & 3555.70 & 13 & 1633.93 & 10 & 3907.79 & 13 \\
\hline 8 & 3779.90 & 13 & 1969.72 & 10 & 4110.31 & 14 \\
\hline 9 & 3966.03 & 13 & 1983.35 & 10 & 4233.92 & 14 \\
\hline 10 & 4170.67 & 14 & 2198.79 & 11 & 4273.31 & 14 \\
\hline 11 & 4941.20 & 14 & 2410.95 & 11 & 4439.64 & 14 \\
\hline 12 & 5234.37 & 15 & 3196.68 & 12 & 4862.91 & 14 \\
\hline 13 & 5561.49 & 15 & 3307.76 & 13 & 4880.93 & 14 \\
\hline 14 & 5662.25 & 15 & 3500.94 & 13 & 5031.95 & 14 \\
\hline 15 & 7407.01 & 16 & 5794.88 & 15 & 5627.21 & 15 \\
\hline 16 & 7438.43 & 16 & 6235.16 & 15 & 5808.85 & 15 \\
\hline 17 & - & - & - & - & 8022.21 & 16 \\
\hline 18 & - & - & - & - & 9433.31 & 17 \\
\hline 19 & - & - & - & - & 10095.26 & 17 \\
\hline 20 & - & - & - & - & 10103.32 & 17 \\
\hline mean $\pm \mathrm{SE}$ & $\begin{array}{c}4031.42 \pm \\
483.43\end{array}$ & $\begin{array}{c}12.8 \pm \\
0.59\end{array}$ & $\begin{array}{c}2368.09 \pm \\
434.37\end{array}$ & $\begin{array}{c}10.56 \pm \\
0.63\end{array}$ & $\begin{array}{c}5022.55 \pm \\
570.78\end{array}$ & $\begin{array}{c}14.3 \pm \\
0.5\end{array}$ \\
\hline \multicolumn{7}{|c|}{$\begin{array}{r}\text { As per Deventer formula - Age of vaccination according to antibody titre of } \\
\text { (excluding birds of higher titre) }\end{array}$} \\
\hline $\begin{array}{r}75 \% \\
\text { flock }\end{array}$ & 5234.37 & 15 & 3196.68 & 12 & 5627.21 & 15 \\
\hline $\begin{array}{l}40 \% \\
\text { flock }\end{array}$ & 3555.70 & 13 & 1633.93 & 10 & 4110.31 & 14 \\
\hline $\begin{array}{l}90 \% \\
\text { flock }\end{array}$ & 7407.01 & 16 & 5794.88 & 15 & 9433.31 & 17 \\
\hline
\end{tabular}


Table.7 Mean maternal antibody titre and age of vaccination in different hatcheries

\begin{tabular}{|c|c|c|c|c|c|c|c|}
\hline \multirow[t]{2}{*}{ Hatchery } & \multirow{2}{*}{$\begin{array}{l}\text { Number } \\
\text { of } \\
\text { samples } \\
(\mathbf{N}) \\
\end{array}$} & \multirow[t]{2}{*}{ Range of MAb titre } & \multirow[t]{2}{*}{$\begin{array}{l}\text { Range of day of } \\
\text { vaccination }\end{array}$} & \multirow[t]{2}{*}{ Mean \pm SE } & \multicolumn{3}{|c|}{$\begin{array}{l}\text { Age of vaccination according to } \\
\text { antibody titre of } \\
\text { (excluding birds with higher titre) }\end{array}$} \\
\hline & & & & & $75 \%$ flock & $40 \%$ flock & $90 \%$ flock \\
\hline $\mathbf{A}$ & 24 & $1668.12-13128.76$ & $10-19$ & $5089.26 \pm 550.62^{\text {efgh }}$ & 15 & 13 & 16 \\
\hline $\mathbf{B}$ & 21 & $678.29-11613.02$ & $7-18$ & $5548.03 \pm 711.71^{\text {fghi }}$ & 16 & 13 & 17 \\
\hline $\mathbf{C}$ & 21 & $1661.03-7223.90$ & $10-16$ & $4488.87 \pm 350.77^{\text {def }}$ & 15 & 13 & 15 \\
\hline $\mathbf{D}$ & 17 & $67.53-518.14$ & 7 & $263.40 \pm 29.42^{\mathrm{a}}$ & 7 & 7 & 7 \\
\hline $\mathbf{E}$ & 17 & 1504.33- 10898.09 & $9-17$ & $7006.25 \pm 705.91^{i}$ & 17 & 16 & 17 \\
\hline $\mathbf{F}$ & 17 & 1715.85- 10600.97 & $10-17$ & $5332.42 \pm 619.89^{\text {fghi }}$ & 16 & 14 & 17 \\
\hline $\mathbf{G}$ & 15 & $271.86-2964.44$ & $7-12$ & $1231.25 \pm 239.65^{\mathrm{ab}}$ & 8 & 7 & 12 \\
\hline $\mathbf{H}$ & 15 & 844.39- 7166.29 & $7-16$ & $3083.54 \pm 445.6^{\mathrm{cd}}$ & 14 & 11 & 14 \\
\hline I & 15 & $331.02-10809.93$ & $7-18$ & $6716.11 \pm 912.06^{\mathrm{ghi}}$ & 17 & 15 & 18 \\
\hline $\mathbf{J}$ & 13 & $814.07-8114.17$ & $7-16$ & $3281.88 \pm 614.19^{\text {cde }}$ & 14 & 10 & 15 \\
\hline $\mathbf{K}$ & 13 & $2-7573.09$ & $7-16$ & $3378.90 \pm 629.51^{\text {cde }}$ & 14 & 10 & 15 \\
\hline $\mathbf{L}$ & 12 & $822.66-7276.52$ & $7-16$ & $3307.08 \pm 590.34^{\text {cde }}$ & 14 & 11 & 15 \\
\hline $\mathbf{M}$ & 10 & $2253.68-11126.05$ & $11-18$ & $5364.99 \pm 765.22^{\text {fghi }}$ & 16 & 13 & 16 \\
\hline $\mathbf{N}$ & 14 & $3040.98-12026.88$ & $12-18$ & $6899.31 \pm 634.72^{\text {ghi }}$ & 17 & 15 & 17 \\
\hline $\mathbf{O}$ & 15 & $1803.59-6655.25$ & $10-16$ & $4585.66 \pm 333.90^{\mathrm{det}}$ & 15 & 13 & 15 \\
\hline $\mathbf{P}$ & 16 & $1410.76-7438.43$ & $9-16$ & $4031.42 \pm 483.43^{\text {cdef }}$ & 15 & 13 & 16 \\
\hline $\mathbf{Q}$ & 16 & $24.97-6235.16$ & $7-15$ & $2368.09 \pm 434.37^{b c}$ & 12 & 10 & 15 \\
\hline $\mathbf{R}$ & 20 & $1156.36-10103.32$ & $8-17$ & $5022.55 \pm 570.78^{\mathrm{efg}}$ & 15 & 14 & 17 \\
\hline Mean & & & $9-16$ & & 15 & 13 & 16 \\
\hline
\end{tabular}

Means with different superscripts are significantly different $(\mathrm{p}<0.05)$ 
Fig.1 ELISA plates showing fluorescence of different intensity in samples depending on the level of IBD antibodies (BG-back ground, PC-positive control, NC-negative control)



Similar study was done by Besseboua et al., (2015) who determined optimal time of vaccination against IBDV (Gumboro) in Algeria. It was noticed that on day 1 the chicks contained a high level (6400.54 \pm 2993.67) of maternally derived antibody that gradually decreased below a positive level within 21 days $(365.86 \pm 634.46)$. It was observed that a high level of MDA interferes with the vaccine virus, resulting in no immune response. For better immune response, it was suggested that the chickens should be vaccinated at day 21 , as the uniformity of MDA is poor (coefficient of variation $[\mathrm{CV}]>30 \%$ ), and boosted at day 28 . Indeed, two vaccinations are necessary to achieve good protection against infectious bursal disease virus of the entire flock. Fantay et al., (2015) also determined optimum time for administration of live intermediate vaccine of infectious bursal disease to chickens at Mekelle farm. The study was conducted from December 2013 to April 2014 to predict the proper age for vaccination of chickens against infectious bursal disease (IBD) and calculate the maternal antibody transfer rate. This study showed that the proper time for administration of live intermediate IBD vaccine is 18 days instead of 21 days with the management conditions in place at the farm. Suzuki et al., (2009) reported that, 15th day is

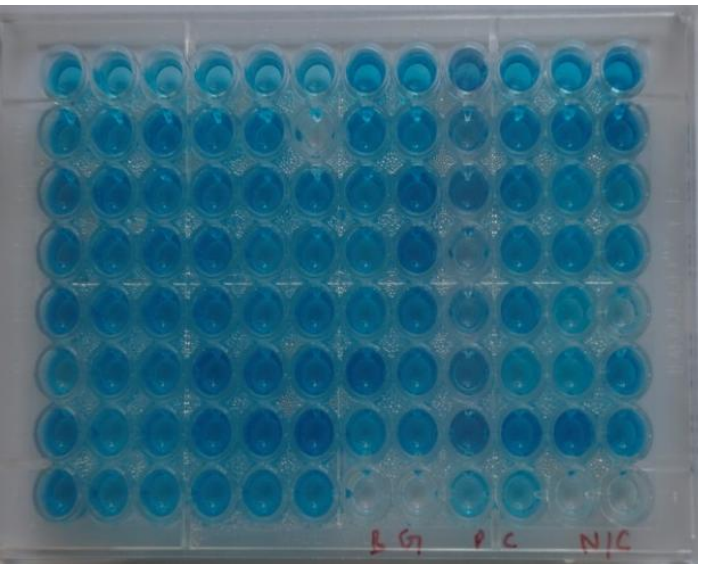

the optimal vaccination time for Gumboro disease which was three days earlier than reported by Fantay et al., (2015). This difference might be due to variation in the type of vaccine used as they used live intermediate plus IBD vaccine instead of intermediate IBD vaccine only.

De Wit (1998) clearly stated that chickens vaccinated using live intermediate IBD vaccine had a capacity to breakthrough maternally derived antibody titre of 125 whereas those vaccinated using intermediate plus IBD had the capacity to break through maternal antibody titre of 500. These substantial differences could be ascribed to the amount of antibodies transferred from hen to chick through the egg (Hamal et al., 2006).

Due to wide range of MAb titre, twice vaccination is advisable for chicks belonging to different hatcheries of Haryana as per our study. The MAb titre calculation is not possible for individual hatchery at moment. Further studies will be required to see the response of IBD vaccination using different vaccines for this schedule.

Maternal antibody titres from the serum samples of day old chicks of 18 hatcheries showed a wide variation. Statistics was 
applied on this raw data and the uniformity of day-old broiler chicks was expressed as percentage of coefficient of variation (CV \%) which was in the range of $28.2 \%$ to $75.3 \%$. Coefficient of variation was very high in all the hatcheries except hatchery $\mathrm{O}$ which indicate non-uniform maternal antibody $(\mathrm{MAb})$ titres in them. The vast range of MAb titre (2 to 13128) in different serum samples gave wide range of day of vaccination as calculated for individual samples of all the hatcheries and it came to be in the range of 7 to 19 days of age of vaccination. According to Deventer formula a flock showing variation of $>4$ days in the age of vaccination range needs to be vaccinated twice. Due to wide range of $\mathrm{MAb}$ titre, twice vaccination is advisable. For this we took average of lowest and highest age for day of vaccination calculated for individual samples of different hatcheries and the age of first vaccination came to be $9^{\text {th }}$ day and age for booster vaccination came to be $16^{\text {th }}$ day. However, further studies are required to strengthen the observations.

\section{References}

Ahmed, Z., Inayat, S., Naeem, K. and Malik, A. 2003. Comparative immune response pattern of commercial infectious bursal disease vaccines against field isolates in Pakistan. Int. J. Poult. Sci. 2 (6): 449453.

Alam, J., Rahman, M.M., Sil, B.K., Khan, M.S.R., Giasuddin and Sarker, M.S.K. 2002. Effect of maternally derived antibody on vaccination against infectious bursal disease (Gumboro) with live vaccine in broiler. Int. J. Poult. Sci. 1(4): 98-101.

Allan, W.H., Faragher, J.T. and Cullen, G.A. 1972. Immunosuppression by the infectious bursal agent in chickens immunized against Newcastle disease. Vet. Rec. 90: 511-512.
Annonymus, 2015. In Research Highlights of 2014-15 of Department of Veterinary Public Health and Epidemiology, Lala Lajpat Rai University of Veterinary and Animal Sciences, Hisar.

Besseboua, O., Ayad, A. and Benbarek, H. 2015. Determination of the optimal time of vaccination against infectious bursal disease virus (Gumboro) in Algeria. Onderstepoort J. Vet. Res. 82(1): 01-06.

Block, H., Block, K.M., Rebeski, D.E., Scharr, H., De Wit, S., Rohn, R. and Rautenschlein, S. 2007. A field study on the significance of vaccination against infectious bursal disease virus (IBDV) at the optimal time point in broiler flocks with maternally derived IBDV antibodies. Avian Pathol. 36(5): 401409.

Brandt, M., Yao, K., Liu, M., Heckert, R.A. and Vakharia, V.N. 2001. Molecular determinants of virulence, cell tropism, and pathogenic phenotype of IBDV. $J$. Virol. 75:11974-11982.

Cao, Y.C., Yung, W.S., Law, M., Bi, Y.Z., Leung, F.C. and Lim, B. 1998. Molecular characterization of seven Chinese isolates of infectious bursal disease virus. Avian Dis. 42: 340-351.

De Wit, J.J. 1998. Gumboro disease: estimation of optimal time of vaccination by the Deventer formula. Polish Vet. J. 3: 19-22.

De Wit, J.J. 2001. Gumboro Disease: estimation of optimal time of vaccination by the Deventer formula. Annual report and proceedings of COST Action 839. Immunosuppressive Vir. Dis. Poult. pp. 170-178.

Dias, A.C., Almeida, R. and Moraes, P. 2009. Sequencing and phylogenetic analysis of the infectious bursal disease virus isolates from outbreak in layer flocks in the state of Minas Gerais. J. Vet. Sci.7: 456-485.

Dobos, P., Hill, B.J., Hallett, R., Kells, D.T., 
Becht, H. and Teninges, D. 1979. Biophysical and biochemical characterization of five animal viruses with bisegmented double-stranded RNA genomes. J. Virol. 32: 593-605.

Fantay, H., Balcha, E., Tesfay, A. and Afera, B. 2015. Determining Optimum Time for Administration of Live Intermediate Vaccine of Infectious Bursal Disease to Chickens at Mekelle Farm. J. Vet. Sci. Technol. 6: 223

Farooq, M., Durrani, F.R., Imran, N., Durrani, Z. And Chand, N. 2003. Prevalence and economic losses due to infectious bursal disease in broilers in Mirpur and Koti districts of Kashmir. Int. J. Poult. Sci. 2: 267-270.

Hair-Bejo, M., Ng, M.K. and Ng, H.Y. 2004. Day-old vaccination against IBD in broiler chickens. Int. J. Poul. Sci. 3: 124-128.

Hamal, K.R., Burgess, S.C., Pevzner, I.Y. and Erf, G.F. 2006. Maternal antibody transfer from dams to their egg yolks, egg whites and chicks in meat lines of chickens. Poult. Sci. 85: 1364-1372.

Hasan, S., Ahmad, K., Fawad, N. and Siddique, B. 1998. A study on the infectious bursal disease around Rawalpindi,Islamabad. Pak. J. Livest. Res. 8: 84-88.

Jackwood, D.J. and Sommer- Wagner, S.E. 2010. Detection and characterization of infectious bursal disease viruses in broilers at processing. Prevent. Vet. Med. 97(1): 45-50.

Jackwood, D.J., Sommer- Wagner, S.E., Stoute, A.S., Woolcock, P.R., Crossley, B.M., Hietala, S.K. and Charlton, B.R. 2009. Characteristics of a very virulent infectious bursal disease virus from California. Avian Dis. 53(4): 592-600.

Khatri, M., Palmquist, J.M., Cha, R.M. and Sharma, J.M. 2005. Infection and activation of bursal macrophages by virulent infectious bursal disease virus.
Virus Res. 113(1): 44-50.

Kim, I.J., Karaca, K., Pertile, T.L., Erickson, S.A. and Sharma, J.M. 1998. Enhanced expression of cytokine genes in spleen macrophages during acute infection with infectious bursal disease virus in chickens. Vet. J. Immunopathol. 61(2): 331-341.

Kouwenhoven, B. and Van den Bos, J. 1994. Control of very virulent Infectious Bursal Disease (Gumboro Disease) in the Netherlands with more virulent vaccines. In: Proceedings of the International symposium on infectious bursal disease and chicken infectious anaemia, Germany. pp. 262-271.

Mcllroy, S.G., Goodall, E.A., Bruce, D.W., Mc Cracken, R.M. and Mc Nulty, M.S. 1992. The cost benefit of vaccinating broiler flocks against subclinical infectious bursal disease. Avian Pathol. 21 (1): 65-76.

Moemen, A.M., Kamal, E. S., Elzanaty, M.B. and Marwa, M.S. 2014. Genetic Characterization of Infectious Bursal Disease Viruses Associated with Gumboro Outbreaks in Commercial Broilers from Asyut Province, Egypt. Hindawi Publishing Corporation ISRN Vet. Sci. Art. ID 916412

Mohanty, G.C., Pandey, A.P. and Rajya, B.S. 1971. Infectious bursal disease in chicken. Curr. Sci. 40: 181-184.

Moraes, H.L.D.S., Salle, C.T.P., Nascimento, V.P.D., Rocha, A.C.G.T. and Souza. G.F.D. 2005. Infectious bursal disease: Evaluation of maternal immunity and protection by vaccination of one-day old chicks against challenge with very virulent virus isolate. Braz. J. Poult. Sci. 7: 51-57.

Nakai, T. and Hirai, H. 1981. In vitro infection of fractionated chicken lymphocytes by infectious bursal disease virus. Avian Dis. 25: 831-838.

Palmquist, J., Khatri, M., Cha, R., Goddeeris, 
B., Walcheck, B. and Sharma, J. 2006. In vivo activation of chicken macrophages by infectious bursal disease virus. Viral Immunol. 19: 305315.

Sharma. J., Kim, I. and Rautenschlein, S. 2000. Infectious bursal disease virus of chickens: Pathogenesis and immune suppression. Dev. Comp. Immunol. 24: 223-235.

Suzuki, K., Caballero, J., Alvarez, F., Faccioli, M., Goreti, M. and Herrero, M. 2009. Simulation models for estimating optimal vaccination timing for infectious bursal disease in broiler chickens in Paraguay. Int. J. Poult. Sci. 8: 559-56

Tsukamoto, K., Tanimura, N., Kakita, S.I., Ota, K., Mase, M., Imai, K. and Hihara, H. 1995. Efficacy of three live vaccines against highly virulent infectious bursal disease virus in chickens with or without maternal antibodies. Avian Dis. pp. 218-229.

Van den Berg, T.P. 2000. Acute infectious bursal disease in poultry: a review. Avian Pathol. 29(1):175-194.

Van den Berg, T.P. and Meulemans, G. 1991. Acute infectious bursal disease in poultry: Protection afforded by maternally derived antibodies and interference with live vaccination. Avian Pathol. 20: 409-421.

Van den Berg, T.P., Gonze, M. and Meulemans, G. 1991. Acute infectious bursal disease in poultry, isolation and characterisation of a highly virulent strain. Avian Pathol. 20: 133-143.

Wyeth, P. J. and Cullen, G.A. 1976. Maternally derived antibody effect on susceptibility of chick to infectious bursal disease. Avian Pathol. 5: 253260.

\section{How to cite this article:}

Pooja Kundu, G. Narang, Naresh Kakkar, Sushma Kajal, Rajesh Chhabra and Mahajan, N.K. 2017. Estimation of Age of Infectious Bursal Disease Vaccination in Broiler Chickens in Haryana, India. Int.J.Curr.Microbiol.App.Sci. 6(12): 3391-3406. doi: https://doi.org/10.20546/ijcmas.2017.612.395 